\title{
Report
}

\section{Environmental health assessment 200 days after earthquake-affected region in East Azerbaijan earthquake, North-Western of Iran, 2012}

\author{
AliHossein Zeinalzadeh ${ }^{1}$, Behrooz Mohammad Alizadeh², Pouran Raeisi ${ }^{3}$, Javad Babaei ${ }^{4}$, Rozita \\ Firooznia 5 , Mohammad Ghanbari Ghozikali ${ }^{6}$, Somaieh Roohani Majd 7 , Mohsen Farajallah Bike \\ Nouri ${ }^{*}$,Khamnian ZHila9.
}

aSocial Determinants of Health Research Center, Associate Professor of Preventive and Community Medicine Department, Faculty of Medicine, Tabriz University of Medical Sciences, Tabriz, Iran

bDeputy of Health ,Tabriz University of Medical Sciences, Tabriz, Iran

'Associate Professor, Working Group on Healthcare Systems, Department of Management and Medical Information, Iran University of Medical Sciences and Healthcare, Tehran, Iran

dPhD Student, Health in Disasters and Emergencies, Faculty of Health, Tehran University of Medical Sciences, Tehran, Iran

eMsc Medical Education, Tabrzi University of Medical Sciences, Tabriz, Iran

fPhD candidate of Environmental Health Engineering, School of Public Health, Tehran University of Medical Sciences, Tehran, Iran

gM.Sc Education Management, Tabriz University Medical of Sciences, Tabriz, Iran

hM.Sc Health Services Management, Tabriz University Medical of Sciences, Tabriz, Iran

iSocial Determinants of Health Research Center, Assistant Professor of Preventive and Community Medicine Department, Faculty of Medicine, Tabriz University of Medical Sciences, Tabriz, Iran.

Geliş tarihi: 23.10.2015, Kabul tarihi:21.05.2016

\begin{abstract}
Evaluating of health status and explore the challenges of health problems that threaten human life following disasters and major earthquakes providing windows of opportunities for health care providers in future planning of disasters. The main purpose of this report was to survey the environmental sanitation statues after 200 days of the affected populations in earthquakes of East Azerbaijan, northwestern of Iran, 2012. The survey was carried out in earthquake zones 200 days after the occurrence of the earthquake.
\end{abstract}

Corresponding Author: Mohsen Farajallah Bike Nouri, M.Sc Health Services Management, Tabriz University Medical of Sciences, Tabriz, Iran, Tlf: +98-914-4063873,

Email:zenalali@gmail.com

Copyright holder Turkish Journal of Public Health

This work is licensed under a Creative Commons Attribution-NonCommercial 4.0 International License. $(\mathrm{cc}) \mathrm{EY}-\mathrm{NC}$ 
A single stage cluster sampling from among 95 villages damaged in the earthquake of 2012 East Azerbaijan of three towns Ahar, Varzeghan and Heris were selected. The data were collected with questionnaire, site visits and evaluation of water and sanitation. In a twin Earthquake, East Azerbaijan province that 399 villages of Ahar, Varzeghan, Heris, Tabriz and Kaleibar cities were affected and 356 (89.2 \%) villages were destroyed between 30-100\%. Evaluation of water and sanitation infrastructure after 200 days, shown that only half of these villages consumed healthy water with high coverage and adequate. Half of the villages in 200 days after the earthquake were covered safe drinking water (treated drinking water). The bacteriological quality of drinking-water supply of the affected area was assessed in randomly collected 146 samples from this region and ten $(6.8 \%)$ reported as unsuitable. Solid waste management facilities in residents have not been acceptable that affect public health. Solid waste disposal was done by district residents (cooperation rural residents) 68.4\%, 36.8\% and 76.3\% in Ahar, Varzeghan and Heris, respectively. Overall, the impact of infectious and communicable diseases after Earthquake was reported $42.1 \%$ (16 villages) in the Varzeghan. The lack of geographical view with a focus in mountainous and rural areas, partial support and dispersion of earthquake-stricken people in affected villages and lack of participatory need assessment and pre-crisis coordination among various organizations led to negative effects of environmental factors on health status in villages. Providing intra-sector coordination for waste management with a sanitary disposal of sewage and detection hazardous materials aftermath as well as immediate measurements in the water supply system are necessary for health promotion of the affected population in the disaster region .

Keywords: Earthquake, Environmental Health, Eastern Azerbaijan.

\title{
Kuzeybatı Iran- Doğu Azerbaycan'da 2012 depreminden etkilenen bölgelerde 200 gün sonra sağlık değerlendirmesi
}

\begin{abstract}
Özet
Afet ve büyük depremler gibi insan yaşamını tehdit eden sağlık sorunlarının incelenmesi ve sağlık durumunun değerlendirilmesi, gelecekte olabilecek afetler için sağllk hizmeti sunucularına plan yapması için olanaklar sağlar. Bu raporun temel amacı, İran'ın kuzeybatısında yer alan Doğu Azerbaycan'da 2012 yılı depremlerinde etkilenen nüfustan 200 gün sonra çevre sağlığı durumunu incelemektir. Tarama deprem meydana gelmesinden 200 gün sonra gerçekleştirilmiştir.

Doğu Azerbaycan depreminde hasar gören 95 köy arasından Ahar, Varzeghan ve Heris adlı üç kasaba küme örnek olarak seçildi. Veriler anket, saha ziyaretleri, su ve sanitasyonun değerlendirilmesi ile toplandı. Doğu Azerbaycan bölgesi ikiz bir depremde Ahar, Varzeghan, Heris, Tabriz ve Kaleibar șehirlerinden 399 köy etkilenmiş ve 356 köy (\%89.2) \% 30-100 arasında yıkılmıștır. Su ve sanitasyon altyapısının 200 gün sonra yapılan değerlendirme, bu köylerin sadece yarısının yeterli ve sağlıklı su tükettiğini; içme suyunun arıtılmasının yapıldığını ve yüksek kapsama alanı olduğunu gösterdi. Depremden sonraki 200 gün içinde köylerin yarısı güvenli içme suyuna (işlenmiş içme suyu) ulaşabiliyordu. Etkilenen bölgenin içme suyunun bakteriyolojik kalitesi, bu bölgedeki 146 örnekten rasgele toplanmıș ve 10'u (\%6.8) uygunsuz olarak rapor edilmiştir. Konutların katı atık yönetim tesisleri, halk sağlığı için kabul edilebilir nitelikte bulunmamıştır. Katı atık bertarafı sırasıyla Ahar, Varzeghan ve Heris'de ilçe sakinleri (kırsal kooperatifi) tarafından \% 68.4, \%36.8 ve \%76.3 olarak gerçekleşti. Genel olarak,
\end{abstract}


Varzeghan'da, deprem sonrasında enfeksiyon ve bulaşıcı hastalıkların etkisi \% 42.1 (16 köy) olarak bildirildi. Dağlık ve kırsal alanlara odaklanan coğrafi yaklaşım eksikliği, etkilenen köylerde depremden zarar gören insanların kısmen desteklenmesi, katılımcı gereksinim değerlendirmesi eksikliği ve çeşitli kuruluşlar arasındaki kriz öncesi koordinasyon eksikliği çevresel faktörlerin sağlık durumu üzerine olumsuz etkilere neden oldu. Afet bölgesinde etkilenen nüfusun sağlığının geliştirilmesi için kanalizasyonun hijyenik değerlendirmesi sonrasında tehlikeli maddelerin tanımlanması, su sisteminde anlık ölçümlerin gerçekleştirilmesi ve atık yönetimi için sektörler arası koordinasyonun sağlanması gereklidir.

Anahtar Kelimeler: Deprem, çevre sağlığı, Doğu Azerbeycan

\section{Introduction:}

Disasters as tragedies usually impose a substantial health burden, directly or indirectly destroy structurally environmental sanitation status in human societies due to serious damage to health facilities and their capacity to address primary health care needs. Today, both frequency and impact of natural disasters as an important part of the health problems have been increasing and affected the lives of people, all around the world. ${ }^{1}$

In the aftermath of disasters, major public health threats such as water supply and sewage systems, jeopardize the lives of the earthquake-affected population that had the highest social and economic impact, especially in developing countries with their high amount of vulnerable poor populations. ${ }^{2,3}$

Iran known as one of the vulnerable region to earthquake all around the world that east Azerbaijan northwest of Iran, earthquake 2012 was one of the most destructive disasters during the last decades. The twin strong earthquakes hit at 4: $53 \mathrm{pm}$ local time and 11 minutes later measured 6 and 6.2 on the Richter scale have hit the cities: Ahar, Varzeghan and Heris in East Azerbaijan in 11 August 2012, claimed the lost lives of 306 and injured more than 3,000 people. ${ }^{4}$ The earthquakes were so intense that more than 272 villages in the area were destroyed and at eight thousand kilometers, the entire infrastructure of water, electricity and sewage systems are heavily damaged that these situations were concerned about the risk of waterborne and communicable disease especially in very crowded shelters ${ }^{5}$
As in any disasters, providing and supervising environmental sanitation services in emergency and months after the earthquake had critical importance of decision making an effective response to disasters and these requires an examination of the status of the situation which is known as health needs assessment in the literature on health care in natural disasters. 6,7 This information is basic for in advance planning for minimizing the effects of disaster at the level of nation, region, community or individual and help in return to normal life quickly if there has been on the use of available resources. ${ }^{4,8}$

Unfortunately, most of the studies in disaster region have only limited to short periods of disasters while getting back to normal life can be as important as save life during disaster period. ${ }^{6-12}$

Although some works have been conducted on consequences of disasters .In a study that was conducted to check the post-quake status of water supply in Bam city, Iran, It is envisaged that $30 \%$ of rural and $70 \%$ of urban water supplies had been destroyed, respectively. That needs to provide sustained effective long-term recovery and reconstruction programs. 13

Usually like other disasters, in East Azerbaijan earthquakes rapid assessment of environmental health need (RAEHN) was performed by the provincial health system for evaluation essential ,urgent and immediate needs of the earthquake affected population but there is no comprehensive data from assessment of environmental health status of after disasters for ensuring a smooth transition of the area into recovery and rehabilitation while, this transition stage is a complicated, systematic, 
and interactive process which needs a more complete understanding of the long-term recovery experiences of people involved. ${ }^{14}$

Thus, the current report, identify problems in the environment, water, sanitation and hygiene situation after earthquake stricken villages of three towns Ahar, Heris and Varzeghan, to apply standards to water supply and install control measures for environmental health problems and finally understand the longterm problems to determine the strengths and weaknesses of conduct programs and modify the existing programs aftermath.

\section{Material and Methods:}

Evaluation of the environmental health status and sanitation: A descriptive survey was performed 200 days after earthquake 2012. For evaluation of the environmental health status and sanitation of earthquakestricked area in the East Azerbaijan province of Iran, which includes the rural districts of Ahar and Varzeghan as well as rural environment that had these components: Household survey, which were collected by a 5-item questionnaire, 7 dimensions checklist and visual inspection of water and sanitation facilities.

1- Five item questionnaire was developed to collect basic data about the status of damaged villages in terms of:

The percentage of villages destroyed by the earthquake, and the number of buildings need to rehabilitation after the earthquake.

2- Seven item checklist was used in this study was developed for evaluation of the status of environmental health in each village was assessed using the mentioned checklists. the local health care centers statues, condition of bathroom and toilet hygiene in the home, population that existing water supply network and access to clean water, safe excreta disposal and waste management; sewage and construction debris; the status of water distribution system and finally communicable disease aftermath.

Content validity of the questions of this checklist was initially approved by professors and experts in the Department of Environmental Health Engineering, and Department of Disaster Management in Tabriz University of Medical Sciences, deputy of halth in the next step, in the implementation stage, necessary changes on the initial items were applied by environmental health engineering and disaster management experts. The internal consistency was examined by Cronbach' alpha (Chronbach' alpha: 0.86), and for reliability determination coefficient of agreement (kappa statistic) was calculated in scoring at 95 percent.

A systematic single stage cluster sampling was implemented, partly drawing on a number of villages damaged in earthquake carried out by the east Azerbaijan District Health Centre. This selected 95 villages $(35 \%$ of 272 total villages damaged) from clusters in the earthquake of 2012 East Azerbaijan, each of which had selected from among the most damaged villages.

Considering that the extent of damage varied in the villages of Ahar, Varzeghan and Heris areas of East Azerbaijan province and that the number of destroyed villages were higher in Varzeghan and Heris. 38 villages were considered for the two towns, whereas only 19 villages (half of the other samples) with higher degrees of damage were selected from Ahar town which was less damaged than the other two districts.

Based on the type of questions in the checklist and the questionnaire, an environmental health survey team that underwent extensive training on both the questionnaire and interview procedures were conducted interviews, observations and necessary descriptive statistics (mean, standard deviation, absolute and relative frequency) were analyzed with the Statistical Package for the Social Sciences (SPSS) 13.0.1 software.

\section{Results} Based on Rapid Assessment of
Environmental Health Need (RAEHN)
data, in a twin Earthquake, East Azerbaijan 
province that 399 villages of Varzeghan, Heris, Ahar, Tabriz and Kaleibar cities were affected 356 (89.2\%) villages destroyed between $30-100 \%$. For secondary evaluation of environmental statues in the affected region About 200 days after earthquakes, our team members that were composed of environmental health officers of Tabriz health center were collecting data only from a sampling cluster affected area with questionnaire and checklist.

Figure 1 indicates the distribution of the rules areas in East Azerbaijan province where earthquake had been occurred.

Because of the different impact of the earthquake on cities, rate of the destruction caused by the earthquake were different in villages of Ahar, Varzeghan and Harris towns and the number of villages destroyed in Harris and Varzeghan section were higher than Ahar.

It was not possible for teams to go to all villages and perform the assessment themselves. Thus, in this survey, the checklists were completed only from 95 villages (35\%) of three districts of Ahar (19 villages), Varzeghan (38 villages) and Heris (38 villages) which were affected by an earthquake.

Among the 19 villages of Ahar city, $36 \%$ (7 villages) had Active Health House, $64 \%$ (12 villages) had lunar villages (villages where there isn't Active Health House and are mobile carried out health services in it), and among the 38 villages of Varzeghan city, 37\% (14villages) had Active Health House, 63\% (24 villages) had lunar villages. Also similar city of Varzeghan, in the 38 villages of Heris city, $37 \%$ (14villages) had Active Health House, 63\% (24 villages) had lunar villages.

According to the results, due to East Azerbaijan twin earthquakes, 97\% (37) surveyed villages in the city Harris, 84\% (32) of the surveyed villages in the city Varzeghan and $74 \%$ (14) of the surveyed villages in the city Ahar were completely destroyed (Figure 2).
The number of buildings and residences in need of rebuilding was estimated in the villages of Ahar, Varzeghan and Harris towns as 6.393, 2.906 and 2.603 units respectively.

In an evaluation of Water, Sanitation and Hygiene (WASH) situation in the affected area, water for daily use was available in most of the affected areas; however, drinking safe water was reported as insufficient in some of the affected villages. The status of water supply in detail is shown in Table 1.

Of the potable water supplies of 95 villages surveyed, a total of 146 cases of microbiological sampling were conducted within three months, 58 cases of which belonged to the villages of Ahar (39.7\%), 49 cases to the villages of Varzeghan (33.6\%), and 39 to the villages of Heris (26.7\%). In our study, 68.5 percent of the villages of Ahar, 58 percent of the villages of Varzeghan, and 50 percent of the villages of Heris were survived for amount of chlorine iodine in drinking water ( based on a free residual chlorine concentration) for disinfection needed depends mainly on the concentration of organic matter in the water by environmental health team and $75 \%$ of Ahar, 27\% Varzeghan and 26\% for Heris villages reported zero in chlorine test and percentage of contaminated water supplies was reported as $57 \%$ for Ahar, $21 \%$ for Varzeghan, and 13\% for Heris.

Household hazardous waste management as one of plans is being revised in this disaster after 200 days.

Insufficient number of sanitation facilities and waste collection system are a common gap identified in all the villages assessed after 200 days; as in $68.4 \%$ of the villages of Ahar, $36.8 \%$ of the villages of Varzeghan, and $76.3 \%$ of the villages of Ahar, $36.8 \%$ of the villages of Varzeghan, and $76.3 \%$ of the villages of Heris, waste materials were collected by the residents themselves. 


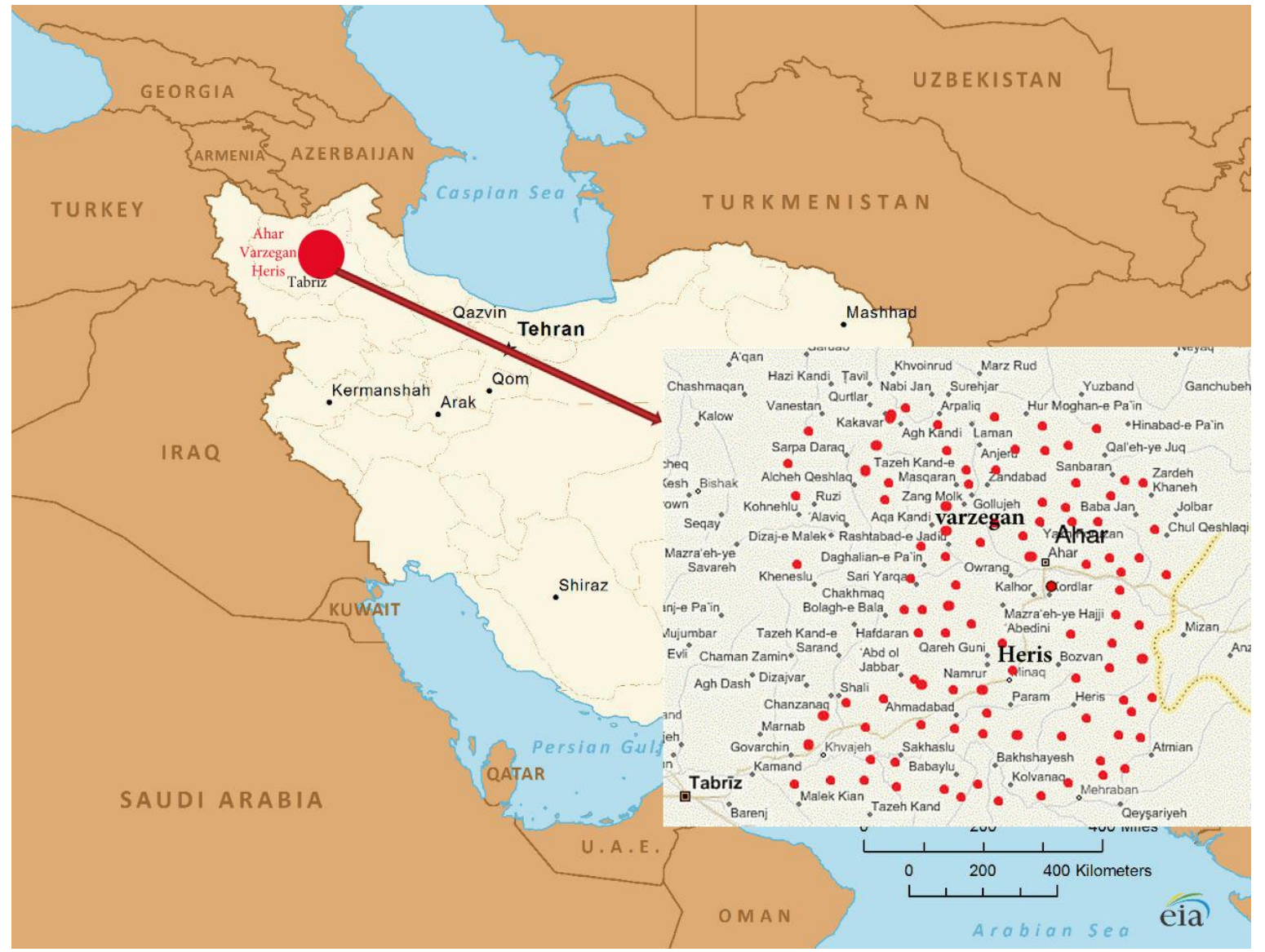

Figure 1. Shows the areas affected by earthquake in East Azarbijan, Iran in 2012

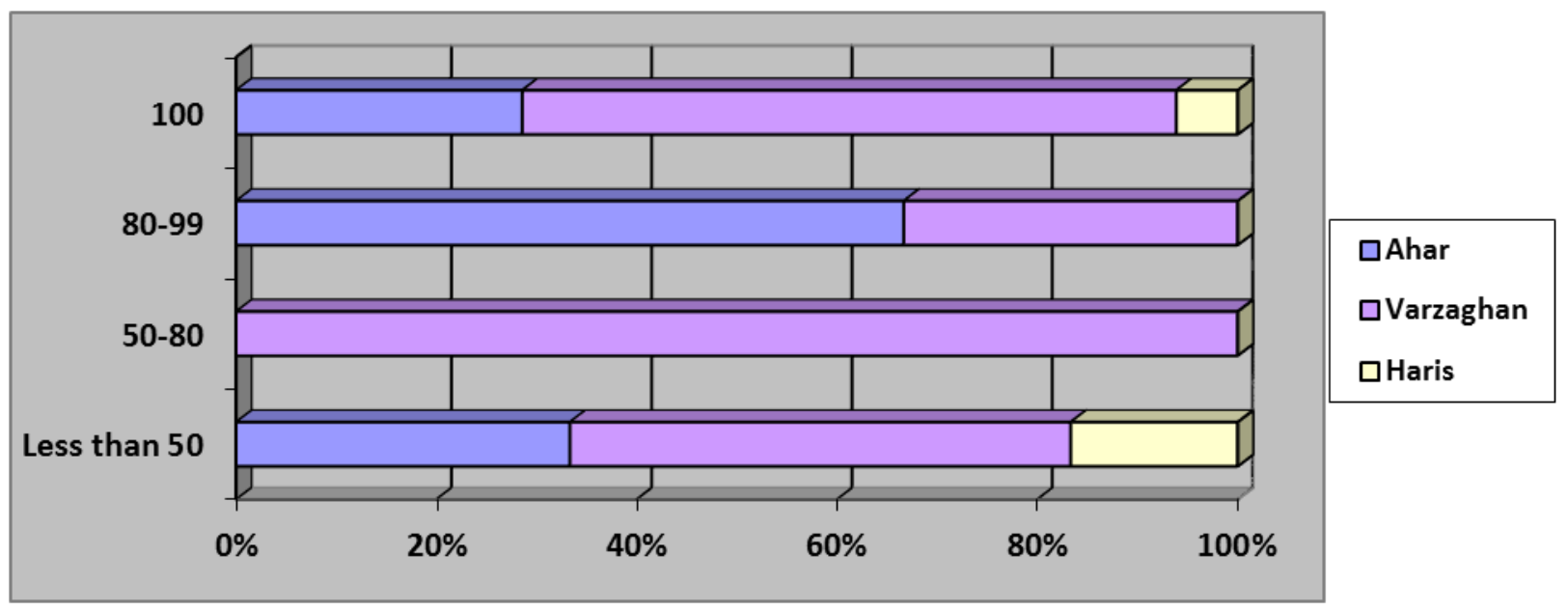

Figure 2: percent of Destruction in the Villages of Ahar, Heris, and Varzeghan 
Table 1: Status of water supply in rural areas damaged

\begin{tabular}{lllll}
\hline District & $\begin{array}{l}\text { Ahar } \\
\mathbf{n}(\%)\end{array}$ & $\begin{array}{l}\text { Varzeghan } \\
\mathbf{n}(\%)\end{array}$ & $\begin{array}{l}\text { Heris } \\
\mathbf{n}(\%)\end{array}$ & Total \\
\hline $\begin{array}{l}\text { The use of safe water supply } \\
\text { networks }\end{array}$ & $11(57.8)$ & $24(63.1)$ & $14(38.5)$ & 49 \\
$\begin{array}{l}\text { The use of problematic water } \\
\text { supply networks }\end{array}$ & $1(5.2)$ & $4(10.5)$ & $4(10.5)$ & 9 \\
$\begin{array}{l}\text { The use of public water supply } \\
\text { The use of renewed resources }\end{array}$ & $1(5.2)$ & $3(7.8)$ & $0(0.0)$ & 4 \\
$\begin{array}{l}\text { The use of non-renewed } \\
\text { resources }\end{array}$ & $4(21.0)$ & $1(2.6)$ & $0(0.0)$ & 0 \\
$\begin{array}{l}\text { The use of fixed tanks } \\
\text { The use of mobile tankers }\end{array}$ & $0(0.0)$ & $1(2.6)$ & $3(7.9)$ & 4 \\
$\begin{array}{l}\text { Two or more above options } \\
\text { Total }\end{array}$ & $2(10.5)$ & $5(13.1)$ & $16(42.1)$ & 23 \\
\hline
\end{tabular}

In other villages, waste materials are not collected and were scattered across the village. In most cases, the rural municipality was the organizer of the waste collection system in the villages. Table 2 . Presents the frequency distribution of waste management organizations in the damaged villages in detail.

For waste water management, in our survey $89.2 \%, \quad 75.5 \%$ and $86.5 \%$ of surveyed families in Ahar, Varzeghan and Heris respectively directed their wastewater into public gutters, while, other household percentage directs their wastewater into absorbing walls.

Almost half of the villages, construction debris had been transferred to a safe place outside the village (Table 3 ).

\section{Recovery and reconstruction phase}

After the disaster, in medium and long term recovery and reconstruction phase, provider organizations should assessed the broader health system parameters such as utilization and quality of health services in the current situation to set priorities. Thus, risk assessments, in this time beyond the RAEHN processes, including hazard, vulnerability and capacity assessments should be conducted to better reconstruct. In East Azerbaijan earthquakes, the process of RAEHN was preformed immediately after the earthquake within 5 days ${ }^{14}$, The main challenges were lack of resources such as an unfavorable situation in the construction of buildings and chaotic environments and calls for attention to engineering and construction principles in the construction of rural buildings. It also highlights the need to improve environmental sanitation to prevent diseases such as diarrhea, infectious hepatitis, skin and eye infections; diseases originating from soil, diseases associated with rodents and diseases originating from drinking water. According to the results of crisis and disaster management system, predicting and taking necessary measures for coping with the damage and losses caused by a disaster is among the crucial issues that should seriously be taken into consideration. ${ }^{8,13}$ 
Table 2: Frequency distribution of waste management organizations in damaged villages

\begin{tabular}{lllllll}
\hline Town & $\begin{array}{l}\text { Rural } \\
\text { municipality }\end{array}$ & $\begin{array}{l}\text { County } \\
\text { municipality }\end{array}$ & $\begin{array}{l}\text { Islamic } \\
\text { Counsel }\end{array}$ & $\begin{array}{l}\text { Lack of } \\
\text { manage } \\
\text { ment }\end{array}$ & Other & Total \\
\hline Ahar & 15.79 & 0 & 5.26 & 15.79 & 63.16 & 100 \\
\hline Varzeghan & 23.68 & 0 & 2.63 & 42.11 & 31.58 & 100 \\
\hline Heris & 23.68 & 5.26 & 7.89 & 26.32 & 36.84 & 100 \\
\hline
\end{tabular}

Table 3: Frequency (percent) distribution of construction debris disposal in the damaged villages

\begin{tabular}{ccccccc}
\hline Town & Safe management & $\begin{array}{c}\text { Unsafe outside } \\
\text { village }\end{array}$ & $\begin{array}{l}\text { Unsafe } \\
\text { inside } \\
\text { village }\end{array}$ & $\begin{array}{l}\text { Unsafe } \\
\text { around } \\
\text { village }\end{array}$ & $\begin{array}{l}\text { Safe } \\
\text { around } \\
\text { village }\end{array}$ & Total \\
\hline Ahar & 43.16 & 20.4 & 5.24 & 11.2 & 20 & 100 \\
\hline Varzeghan & 62.03 & 10.53 & 12.22 & 6.2 & 9.02 & 100 \\
\hline Heris & 47.03 & 22.24 & 2.63 & 14.6 & 13.5 & 100 \\
\hline
\end{tabular}

Unhealthy water supply systems in East Azerbaijan district months after disaster was one of the most important challenges. There were only in half of the villages surveyed had access to healthy water supplies. This problem was mostly caused by the more distances between the villages and lack of convenient access by water supply reconstruction teams in the villages. However, the officials had to put more efforts to solve the problems in the earthquake-stricken area and nearly seven months after the earthquake, water supply conditions in these areas had reached a more favorable situation. One of the most important parameters in the drinking water quality control that should be paid a special attention in periods of disaster is continues assessment of the bacteriological status of water. The results of study conducted with Mahvi et al highlight the importance of preparedness water that is available to the public should be free of contamination in bacteriological terms. ${ }^{4}$

Water supply assessment in region affected by disasters the most important challenges that researcher experienced were more than half of the possible water supplies of Ahar, quarter supplies of Varzeghan and Heris, residual chlorine was reported as zero. In a study conducted by Moosavi and Mahvi (2007), titled Water Supply Assessment in Bam after the Earthquake, 30 percent of the wells and water supply lines and 70 percent of the distribution network were destroyed. Postcrisis water distribution was carried out through distribution networks in camps, the old urban distribution network, and 65 mobile tankers. Among 3,170 microbiological samples, $473 \quad$ (14.9\%) samples were reported as undesirable and $10 \%$ as contaminated. The results of testing for chlorine in the drinking water showed 
that $10 \%$ of potable water supplies had zero residual chlorine. In these villages, water was provided by the use of public water supplies, fixed tanks and mobile tankers. Among the problems associated with fixed water supplies are: high temperature in the warmer months, lack of enough water pipes or the installation of pipes in unsuitable conditions, and lack of proper drainage for the wastewater. $^{3}$ Therefore, long term efforts should be made in order to repair and operate water supply and water distribution networks. Considering the occurrence of earthquakes in the hot season and a greater need for drinking water in the first days after the earthquake, the use of bottled water by residents of the damaged villages had an important role in preventing water-borne diseases. In this earthquake, the use of bottled water was deemed necessary in the early days of the crisis and continued until the assignment of a certain custodian and the provision of drinking water sources in the damaged areas. 17-20

As Mosaferi et al. found in their study "Issues in Environmental Health in the Earthquake of 2012 in East Azerbaijan: Shortfalls and Solutions", lack of an organizing custodian for the installation of sanitary toilets, waste disposal systems and sewage in the damaged areas was among the major problems in the first weeks after the earthquake. ${ }^{18}$

In this study, these problems were clearly evident and lack of an organizing custodian for the installation of hygienic baths and toilets in the damaged areas was among the main problems and challenges which continued to persist for some time. Disaster management is associated with numerous problems in Iran due to lack of coordination among responsible agencies especially in dealing with large and pervasive disasters. ${ }^{11,14}$ The results of a study by Hajinejad et al. aimed to identify development opportunities caused by earthquakes with an emphasis on the physical dimensions of the city of Bam indicate that infrastructure services such as wastewater were ignored in the earthquake of Bam whereas housing and educational facilities were given much more attention at the time of disasters. This view is a wakeup call for infectious disease outbreaks. ${ }^{20}$ The findings obtained from the status of sewage and waste within 200 days after the quake in the damaged areas suggests the persistence of this problem. Government agencies, including urban, county and rural municipalities had a very small role in waste and wastewater management. Where the situation was relatively good, one could see the role of public participation by rural residents. The findings of this study imply the disregarding of organizations related with sewerage and waste management in disaster situations. Whereas 120 tons of waste was generated before the earthquake of Bam, this amount reached 200 tons after the earthquake. Since most of the survivors were resettled in camps, waste collection and wastewater management were easier. ${ }^{19,20}$ However, in the earthquake of Azerbaijan, because of the vastness of the damaged areas and the high dispersion of resettlement centers for the survivors, the situation was difficult and waste management was faced with numerous problems.

\section{Conclusions and Recommendations:}

The earthquake of Azerbaijan is a wakeup call for the possible occurrence of similar events in other parts of the country and requires a strategic planning to reduce the adverse impact of such events. Despite the timely deployment of operational environmental health teams immediately following the earthquake in damaged areas, infrastructure activities for the resolution of problems associated with waste management, water supply, sewage systems, and proper bathrooms and sewers were not conducted in a satisfactory way. For rebuilding and restoring these systems, there is the need for coordination among various bodies and planning ahead of time for disaster.

Due to lack of timely organization of agencies in the area and neglect of the authorities related to water, sanitation and rural waste, immediate infrastructure measures were not taken to solve the 
problems. This led to an unsatisfactory situation in the health status of rural areas in 200 days after the earthquake. The earthquake of Azerbaijan is a wakeup call for various organizations in Iran for coordinating and planning in order to cover all aspects of earthquake risk. This issue is very important especially in situations where such events in rural areas coincide with high geographical distribution and population. We must learn and gain the necessary experience from these events. Therefore, according to the above discussion, the following guidelines are recommended for the improvement of disaster management in the event of a disaster:

- Recognition of disaster management staff and administration and making preparations in their members to make good decisions in times of disaster

- Identification of the overall situation in various parts of the country in terms of high disaster

risk - Clear separation of the duties of organizations and agencies involved in disaster management

- Pilot maneuvers to prepare and enable the operational teams

- Lack of an organizing custodian for the installation of hygienic baths and toilets in the damaged areas was among the main problems and challenges which continued to persist for some time. Therefore, it is recommended that the authorities take the necessary measures in this relation and clarify the duties before the occurrence of a disaster

- The use of bottled water in the early days of the disaster until the assignment of a certain custodian and the provision of drinking water sources in the damaged areas

- The utilization of proper waste management systems and construction debris disposal in the damaged areas

- Epidemiological study about environmental health is necessary after disaster
Limitations in this study were lack of expert fore data collection, more distances between villages, and their high dispersion, especially in the cold (winter) season. The strengths of this study were the public participation and institutions involved.

\section{Acknowledgements}

We hereby express our sincere gratitude to experts of East Azerbaijan Health Center and experts of Ahar, Varzeghan, and Heris towns for their sincere cooperation with the research team.

\section{References}

1. Moosavi AR, Mahvi AH. Supply situation after the earthquake in Bam. Journal of Energy and Hydro Technology. 2008; 1(2):37-2.[ In Persian ]

2. Naddafi $K$, Yonesi $B$, Taheri $T$. Emergency sanitation: assesment and programme design. Tehran: Nas; 2009.

3. Mahvi A. H., Omran GH. A., Asgari A. R. Bam City Solid Wastes Management, Before and After the Earthquake of 26 December 2003. Journal of Military Medicine. 2006; 8(2):83-9. [In Persian]

4. Ghabili, Kamyar, et al. "Lessons from the recent twin earthquakes in Iran." PLoS currents 4 (2012).

5. Rikhtegar, Reza, Sina Zarrintan, and Farzad Kakaei. "Recent twin earthquakes in Iran: was volunteer assistance effective?" Prehospital and disaster medicine 28.03 (2013): 311.

6. Toole, Michael J., and Ronald J. Waldman. "THE PUBLIC HEALTH ASPECTS OF COMPLEX EMERGENCIES AND REFUGEE SITUATIONS 1." Annual review of public health 18.1 (1997): 283-312.

7. Gautschi OP, Cadosch D, Rajan G, Zellweger $R$. Prehosp Disaster Med. 2008 Mar-Apr; 23(2):195-201.

8. Tobin, Graham A. "Sustainability and community resilience: the holy grail of hazards planning." Global 
Environmental Change Part B: Environmental Hazards 1.1 (1999): 1325.

9. Galea, Sandro, Arijit Nandi, and David Vlahov. "The epidemiology of posttraumatic stress disorder after disasters." Epidemiologic Reviews 27.1 (2005): 78-91.

10. Birkland, Thomas A. After disaster: Agenda setting, public policy, and focusing events. Georgetown University Press, 1997.

11. Quarantelli, Enrico L. "Catastrophes are different from disasters: some implications for crisis planning and managing drawn from Katrina." Understanding Katrina: Perspectives from the social sciences (2005).

12. Bengtsson, Linus, et al. "Improved response to disasters and outbreaks by tracking population movements with mobile phone network data: a postearthquake geospatial study in Haiti." PLoS medicine 8.8 (2011): e1001083.

13. Emami, Mohammad J., et al. "Strategies in evaluation and management of Bam earthquake victims." Prehospital and disaster medicine 20.05 (2005): 327330.

14. Babaie, Javad, Shandiz Moslehi, and Ali Ardalan. "Rapid Health Needs Assessment Experience in 11 August 2012 East Azerbaijan Earthquakes: A Qualitative Study." PLoS currents 6 (2013).
15. Shaluf, Ibrahim M., and Aini Mat Said. "A Review of disaster and crisis." Disaster Prevention and Management 12.1 (2003): 24-32.

16. Kemp, Geoffrey, and John Allen Gay. War with Iran: Political, Military, and Economic Consequences. Rowman \& Littlefield Publishers, 2013.

17. Seyf N. Environmental health measures to reduce the impacts of natural disasters. Tehran: National Committee on Interior Ministry to reduce the impact of natural disasters; 2002. [ In Persian ]

18. Mosaferi M, Jahani Moghadam J, Yosefi R, Poor Akbar M, Naghipoor N. Environmental health issues in the earthquake of 1391 in East Azarbaijan: Deficits and strategies .DEPICITION OF HEALTH. 2012;2-3[ In Persian ]

19. Araghizadeh H., Saghafi Nia M., Entezari V. Analyzing medical management in disasters: A Review of the Bam Earthquake experiences. Journal of Military Medicine. [Research]. 2004;5(4):259-68. [ In Persian ]

20. Hajinezhad A, Asgari A, Rafeian M, Moohamadi S. Identifying development opportunities earthquake with an emphasis on the physical aspects of the case: Bam. Geography and Development. 1389;8(19):71-82. [In Persian] 